\title{
Derogation in the Field of Human RIGHTS: INTERNATIONAL LEGAL INSTRUMENTS AND Practice of UKRAINE
}

\author{
Volodymyr Denysov \& Lyudmyla Falalieieva \\ National Academy of Sciences of Ukraine, Kyiv, Ukraine \\ volodymyrden@ukr.net; lyudmilafal@ukr.net
}

DENYSOV, Volodymyr; FALALIEIEVA, Lyudmyla. Derogation in the Field of Human Rights: International Legal Instruments and Practice of Ukraine. International and Comparative Law Review, 2020, vol. 20, no. 2, pp. 7-37. DOI: 10.2478/iclr-2020-0016

\begin{abstract}
Summary: The study highlights the international legal framework for the regulation of derogation of human rights and the practice of applying the latter by Ukraine, which is exercised for the first time under conditions of armed conflict and temporary loss of control over part of its territory. The essence, factors, mechanisms, peculiarities and problems related to derogation in the field of human rights, tools for its realization are revealed. The importance of using derogation of human rights as one of the "escape mechanisms" for the state is emphasized, the state's right which is of an exclusive nature, the possibility of which is provided for by the relevant international treaty, requiring compliance with agreed conditions and procedures. Comparative analysis of the provisions of International Covenant on Civil and Political Rights (1966), Convention for the Protection of Human Rights and Fundamental Freedoms (1950) concerning the right of the state to derogate in the field of human rights in time of a public emergency threatening the life of the nation is made. It is emphasized that the derogation in the field of human rights requires doctrinal understanding as a kind of legitimate limitation on use of restrictions on rights. It outlines the specific measures Ukraine was forced to take in order to derogate in the field of human rights under the armed conflict and temporary loss of control over part of its territory, as well as their perception by the international community. International legal acts, case law of the European Court of Human Rights and doctrinal views on issues outlined are analyzed.
\end{abstract}

Keywords: international human rights law, International Covenant on Civil and Political Rights (1966), United Nations Human Rights Committee, Office of the United Nations High Commissioner for Human Rights, Council of Europe, Convention for the Protection of Human Rights and Fundamental Freedoms (1950), European Court of Human Rights, public emergency, threat to the life of the nation, derogation, human rights.

\section{Introduction}

The fundamental socio-political changes caused by the understanding of the numerous human losses and the rational factors of overcoming the devastating 
consequences of World War II, identified the main vectors of the evolutionary development of a bloodless Europe, the need to take political and legal measures, the search for common values and founding principles that are at the heart of democracy based on respect for human rights and the rule of law. By ensuring the application of European standards, inter alia in the field of human rights, the Council of Europe is actively involved in shaping the European legal space and also contributing to the establishing of a single European space that is the embodiment of the idea of a United Europe. The Council of Europe maintains high European standards and accumulates the best practices for their implementation in various ways, taking a prominent place in the institutional architecture of European international law, forming part of international institutional law. At the same time, in the situation of the return of the Russian Federation and the restoration of the rights of its delegation to the Parliamentary Assembly of the Council of Europe (resolution approved on 25 June 2019), due to absence of any constructive steps and continuous neglect, gross violation of all basic principles of international law that serve as decisive and fundamental for modern world order in the relevant spheres of international relations, ${ }^{1}$ the Council of Europe demonstrated a change of approaches, a certain reassessment of values, lack of common strategy in Europe, and as a result, such a concession was possible.

Obviously, the multifaceted activities of the Council of Europe forms new political and legal dimension of the European continent, contributing to the promotion of European identity (in a broad sense), taking the international standards of respect for human rights as one of the fundamental values of a democratic society based on the rule of law. It is noteworthy that the Council of Europe has worked out the political and legal framework for regulating the cooperation of European states, promoted the removal of human rights protection from the sphere of internal state competence, besides encouraged comprehensive and systematic enhancing of legislative support taking into account development dynamics of European and other international standards, which prompts to be guided by them during law enforcement and to correct it in a timely manner. However, there is a certain asymmetry in the expectations and opportunities for peace-building and stability in the 21 st century Europe ${ }^{2}$ "the pursuit of peace

1 See DENYSOV, Volodymyr. Pryntsypy mizhnarodnoho prava. Entsyklopediia mizhnarodnoho prava: U 3 t. Redkol.: Yurii Shemshuchenko, Volodymyr Denysov (spivholovy) ta in.; Instytut derzhavy i prava im. V. M. Koretskoho NAN Ukrainy. T. 3 (M-Ia). Kyiv: Akademperiodyka, 2019, pp. 623-624; ZADOROZHNII, Oleksandr. Mizhnarodne pravo v mizhderzhavnykh vidnosynakh Ukrainy i Rosiiskoi Federatsii 1991-2014: monohrafiia. Kyiv: K.I.S., 2014, pp. 637-638; ZADOROZHNII, Oleksandr. Aneksiia Krymu - mizhnarodnyi zlochyn: monohrafiia. Kyiv: K.I.S., 2015, pp. 416-422.

2 FALALIEIEVA, Liudmyla. Rada Yevropy ta Yevropeiskyi Soiuz: osoblyvosti pravovoho statusu, uzghodzhennia standartiv pravozakhystu. Visnyk Kyivskoho natsionalnoho universytetu imeni Tarasa Shevchenka. Mizhnarodni vidnosyny, 2018, vyp. 1/2 (47/48), p. 58. 
based upon justice and international co-operation is vital for the preservation of human society and civilisation"3 (preamble to the Council of Europe Statute).

In the face of armed conflict, temporary loss of control of part of the state territory by the Ukrainian authorities, Ukraine, as a State Party to numerous international human rights treaties, is forced to exercise its right using flexibility of the applicable legal framework and resorting to practice of derogation of human rights. In such a situation, it is about derogation as one of the "escape mechanisms" for the state, its right, which is of an exceptional nature, the possibility of which is provided for by the relevant international treaty, requiring compliance with agreed terms and procedures.

\section{Convention for the Protection of Human Rights and Fundamental Free- doms (1950) as the treaty "hard core" of the Council of Europe}

The Council of Europe's treaty practice is aimed at finding an acceptable model of international legal cooperation. The treaties of the Council of Europe promote harmonization and enhancement of national legislation and practice on the basis of European standards as their "strategic rationale". According to the organizational effect, international treaties of the Council of Europe are distinguished, inter alia, by providing for the establishment of a mechanism for monitoring their implementation, determine its authority to decide on compliance or non-compliance by States Parties with their obligations. The Council of Europe has put in place an effective system for the protection of human rights, the treaty "hard core" of which has been the Convention for the Protection of Human Rights and Fundamental Freedoms (1950) (hereinafter referred to as ECHR, Convention (1950); as of that date, 47 states had ratified), which contains a catalog of collectively guaranteed human rights and provides for the establishment of an unprecedented convention control mechanism, an international jurisdictional body for their protection - European Court of Human Rights (hereinafter - ECtHR). It not only ensures that States Parties fulfill their obligations under the Convention, but also interprets the provisions of the ECHR and annexed to it Protocols, including the exclusive right to derogation.

The European system of human rights protection has proven to be the most effective regional system, recognized as an achievement of the Council of Europe, and promotes its leading role in European institutional architecture. Actually, High Contracting Parties of the ECHR, according to Article 1, pledged to respect human rights by guaranteeing to everyone under their jurisdiction the rights and freedoms

3 Statute of the Council of Europe and texts of statutory character. London, 5.V.1949. [online]. Available at: <https://rm.coe.int/CoERMPublicCommonSearchServices/ DisplayDCTMContent?document Id=0900001680935bd5> Accessed: 17.02.2020

4 Convention for the Protection of Human Rights and Fundamental Freedoms as amended by Protocols No. 11 and No. 14. Rome, 04.XI.1950. [online]. Available at: <https://rm.coe. int/1680063765> Accessed: 10.02.2020 
defined in section I of this international legal act, as Professor V. Mitsik notes, it is "the jurisdiction of the state, not the nationality or territory, that is decisive for the ensuarance and protection of conventional rights and freedoms."

The ECHR was adopted as "an instrument designed to maintain and promote the ideals and values of a democratic society"6 (ECtHR's judgment in case of Kjeldsen, Busk Madsen and Pedersen v. Denmark (1976)), for the practical implementation of statutory ideas and goals, fundamental values and principles of the Council of Europe, creating conditions for an effective democracy, which is gradually evolving, contributing to the establishment and development of the European legal space, as well as ensuring a high level harmonization of national legislation and practice of European states ${ }^{7}$ based on the approach of respect for human rights. The ECtHR has emphasised the 1950 Convention's role as a "constitutional instrument of European public order" in the field of human rights ${ }^{8}$ (Bosphorus Hava Yollari Turizm ve Ticaret Anonim Şirketi v. Ireland (2005)). Eventually, the substantive guarantees of the ECHR" - as a "European code of freedom and democracy,"10 backed up by the ECtHR's case law as an "important European actor,"11 have explicitly influenced the interpretation of human rights not only at the national level but also at the European Union level (established as general principles of EU law), setting a minimum European standard which cannot be below neither for the state nor for the supranationa ${ }^{12}$ integration entity in law-making and law-enforcement practice can guarantee these rights.

5 MYTSYK, Vsevolod. Yevropeiska konventsiia pro zakhyst prav liudyny i osnovopolozhnykh svobod 1950. Entsyklopediia mizhnarodnoho prava: U 3 t. Redkol.: Yurii Shemshuchenko, Volodymyr Denysov (spivholovy) ta in.; Instytut derzhavy i prava im. V. M. Koretskoho NAN Ukrainy. T. 2 (E-L). Kyiv: Akademperiodyka, 2017, p. 128.

6 Case of Kjeldsen, Busk Madsen and Pedersen v. Denmark (Application no. 5095/71; 5920/72; 5926/72): Judgment European Court of Human Rights, 7 December 1976. [online]. Available at: <https://www.globalhealthrights.org/wp-content/uploads/2013/10/Kjeldsen-Denmark-1976.pdf> Accessed: 23.02.2020

7 FALALIEIEVA, Liudmyla. Rada Yevropy. Entsyklopediia mizhnarodnoho prava: U 3 t. Redkol.: Yurii Shemshuchenko, Volodymyr Denysov (spivholovy) ta in.; Instytut derzhavy i prava im. V. M. Koretskoho NAN Ukrainy. T. 3 (M-Ia). Kyiv: Akademperiodyka, 2019, p. 663.

8 Case of Bosphorus Hava Yollari Turizm ve Ticaret Anonim Şirketi v. Ireland (Application no. 45036/98, \$ 156): Judgment European Court of Human Rights, 30 June 2005. [online]. Available at: <https://hudoc.echr.coe.int/eng\#\{“itemid”:[“001-69564”]\}> Accessed: 12.02.2020

9 See DÖRR, Oliver. European Convention on Human Rights. The Council of Europe: Its Law and Policies. Ed. by Stefanie Schmahl, Marten Breuer. Oxford: Oxford University Press, 2017, pp. 490-500.

10 BUROMENSKYI, Mykhailo. Yevropeiskyi kodeks svobody ta demokratii. Pravo Ukrainy, 2010, № 10, p. 89.

11 ABDELGAWAD, Elisabeth, Lambert. European Court of Human Rights. The Council of Europe: Its Law and Policies. Ed. by Stefanie Schmahl, Marten Breuer. Oxford: Oxford University Press, 2017, p. 238.

12 See DENYSOV, Volodymyr, FALALIEIEVA, Liudmyla. Nadnatsionalnist yak pravova realnist mizhnarodnoi intehratsii. Pravo Ukrainy, 2018, № 1, pp. 214-229. 
A comparative analysis of judgments adopted in Ukraine suggests that the number of appeals to the ECHR has increased and the ECtHR's case law has become more common. The judicial implementation of the 1950 Convention in Ukraine is one of the key indicators of the fulfillment of its treaty obligations by the state, though up to now it has no general character, its impact on the law enforcement practice, the judicial practice could be far-reaching, this is what the Law of Ukraine "On the enforcement of judgments and the application of the case law of the European Court of Human Rights" of 23 February 2006 No. $3477-\mathrm{IV}^{13}$ is aimed at.

The Office of Council of Europe in Ukraine coordinates the implementation of Council of Europe cooperation programmes in the country, from 2018 concentrates activities on fewer projects, supports consolidation of ongoing efforts to meet its obligations before the Council of Europe Action Plan for Ukraine for 2018-2021, ${ }^{14}$ approved on 21 February 2018 by the Committee of Ministers of the Council of Europe, which is a strategic programming instrument for cooperation in priority areas and exchange of best practices. It is within the framework of this Action Plan that the Council of Europe's project "Internal Displacement in Ukraine: Building Solutions" is implemented and aimed at enhancing the legal framework and legal practice regarding internal displacement, as one of the important human rights, through the introduction of mechanisms and procedures based on European and other international standards for the protection of the rights of internally displaced persons, expanding their capacities and strengthening their ability in the field of human rights protection, access to justice, which is one of the key indicators of Ukraine's proper fulfillment of its obligations in this area. At the same time, some projects are being implemented within the framework of joint programs of the Council of Europe and the European Union as a special international legal form of cooperation between them and Ukraine - the state of their conduct, in particular "the Partnership for Good Governance”.

\section{The right to derogate through the prism of compliance with treaty con- ditions and procedures}

On Ukrainian territory, so in Europe, armed conflict continues for the seventh consecutive year with gross and systematical violation of human rights and it actualises the need to expand the ability to comply with international stand-

13 Pro vykonannia rishen ta zastosuvannia praktyky Yevropeiskoho sudu z prav liudyny: Zakon Ukrainy vid 23 liutoho 2006 r. № 3477-IV u redaktsii vid 2 hrudnia 2012 r. № 5463-VI. Vidomosti Verkhovnoi Rady Ukrainy, 2006, № 30, St. 260. [online]. Available at: $<$ https://zakon.rada.gov.ua/laws/show/3477-15> Accessed: 27.02.2020

14 See Council of Europe Action Plan for Ukraine 2018-2021. GR-DEM(2017)18. 21 February 2018. Document prepared by the Office of the Directorate General of Programmes. Document approved by the Committee of Ministers of the Council of Europe on 21 February 2018 (CM/Del/Dec(2018)1308/2.1bisc), 43 p. 
ards and to build the capacity to fulfill international treaty obligations in the field of protection of human rights, protection of the civilian population. In the armed conflict, temporary loss of control over part of Ukraine's territory by the Ukrainian authorities, new geopolitical realities, the State Party of many international human rights treaties is forced to exercise its right using flexibility of the applicable legal framework and resort to the practice of derogation of human rights. In fact, we are talking about derogation as a so-called "rational response", one of the fuses, "escape mechanisms" for the state, its right, which has an exclusive character, the possibility of implementation of which is provided for by the relevant international treaty, requiring strict compliance with the agreed terms and procedures.

The International Covenant on Civil and Political Rights (1966) ${ }^{15}$ (hereinafter referred to as the ICCPR; as of that date, 173 states had ratified ${ }^{16}$ ) and the ECHR contain derogation clause on the basis and in the order defined in Article 4 of the first and Article 15 of the second, respectively. Mentioned international legal acts constitute the core of universal and regional systems of human rights protection, which, on the one hand, differ in features and, on the other - have many similar, for the most part, coinciding. Thus, Article $4 \$ 1$ of the ICCPR states that, in time of a public emergency which threatens the life of the nation and the existence of which is officially proclaimed, the States Parties to the present Covenant may take measures derogating from their obligations under the present Covenant to the extent strictly required by the exigencies of the situation, provided that such measures are not inconsistent with their other obligations under international law and do not involve discrimination solely on the ground of race, color, sex, language, religion or social origin. It is noteworthy that Article 15 of the ECHR does not contain a requirement for a official proclamation of a public emergency in a country threatening the life of the nation. As the ECtHR found in the judgment in Lawless v. Ireland (1961) it is considered sufficient if its existence can be proved from the facts available or from the totality of those facts ( $\$ 5-9) .{ }^{17}$ In addition, in Article 15 of the ECHR, the non-discrimination condition was not written out separately but was considered by the ECtHR as an element of the principle of proportionality ${ }^{18}$ (A. and Others $v$. The United King-

15 International Covenant on Civil and Political Rights. New York, 19 December 1966. [online]. Available at: $<\mathrm{http} / / / w w w . u n . o r g . u a /$ images/International_Covenant_on_Civil_ and_Political_Rights_CCPR_eng1.pdf > Accessed: 10.03.2020

16 Status of International Covenant on Civil and Political Rights. [online]. Available at: $<$ https:// treaties.un.org/Pages/ViewDetails.aspx?src=TREATY\&mtdsg_no=IV-4\&chapter=4\&clang= en> Accessed: 26.02.2020

17 Case of Lawless v. Ireland (No. 3) (Application no. 332/57): Judgment European Court of Human Rights, 1 July 1961. [online]. Available at: <https://hudoc.echr.coe.int/ eng\#\{“itemid":[“001-57518”]\}> Accessed: 14.03.2020

18 Case of A. and Others v. the United Kingdom (Application no. 3455/05): Judgment European Court of Human Rights, 19 February 2009. [online]. Available at: <https://hudoc. echr.coe.int/eng\#\{“itemid”:[“001-91403”]\}> Accessed: 11.03.2020 
dom (2009)). In Article $4 \$ 2$ of the ICCPR, it was emphasized that the above mentioned provision could not justify any derogation from Article 6 (right to life), Article 7 (prohibition of torture), Article $8 \$ 1,2$ (prohibition of slavery), Article 11 (prohibition of imprisonment merely on the ground of inability to fulfil a treaty obligation), Article 15 (prohibition of being held guilty of any criminal offence on account of any act or omission which did not constitute a criminal offence), Article 16 (right to recognition everywhere as a person before the law), Article 18 (the right to freedom of thought, conscience and religion). Moreover, Article $4 \$ 3$ defines that any State Party to the present Covenant availing itself of the right of derogation shall immediately inform the other States Parties to the present Covenant, through the intermediary of the UN Secretary-General, of the provisions from which it has derogated and of the reasons by which it was actuated, as well as on the date on which it terminates such derogation.

On June 5, 2015, Ukraine informed the United Nations Secretary-General about the security situation in Donetsk and Luhansk areas, which forced state authorities to apply Artice 4 of the ICCPR for the purpose to derogate from the obligations under this international legal act concerning certain rights guaranteed by it, namely: the right to an effective remedy (Article $2 \S 3$; however, derogation from the obligations under this paragraph, as interpreted by the UN Human Rights Committee, is not permitted ${ }^{19}$ ); right to freedom from arbitrary detention and appropriate procedural safeguards (Article 9); the right to liberty of movement and freedom to choose his residence (Article 12); the right to a fair trial (Article 14); the right to respect of private and family life (Article 17). Shortly afterwards, on November 27, 2015, Ukraine notified the UN SecretaryGeneral, as a depository of international treaties, of territories temporarily out of its control in whole or in part, for which Ukraine exercised its right of darogation from certain obligations under the ICCPR. However, the notifications submitted by Ukraine (Verbal Notes No. 4132/28-194/501-803 dated June 5, 2015, No. 4132/28-194/501-1987 dated November 24, 2015, No. 4132/2+; 94/501-1792 dated July 6, 2016, No. 4132/28-194/501-128 dated January 20, 2017, and No. 4132/23-194/501-2057 dated November 26, 2019) in accordance with Article 4 $\$ 3$ of the ICCPR raised the concern of the Office of the UN High Commissioner for Human Rights regarding the lawfulness of a derogation dependent on the fulfillment of a number of specific requirements set out in this article. The analysis of the derogation gave rise to the conclusion that, in particular: "1) The information provided in notifications of June and November 2015 is not sufficient to justify the lawfulness of the derogation for the following reasons: a) The Government of Ukraine has not declared a public emergency officially as required under Article 4 of the ICCPR. b) The duration, geographical coverage and taken measures for derogation do not appear to be clearly limited by the

19 Analitychna dovidka pro vidstup Uriadu Ukrainy vid okremykh zobov'iazan zghidno z mizhnarodnymy uhodamy pro prava liudyny, storonoiu yakykh ye Ukraina. 20 travnia 2016 roku. Upravlinnia Verkhovnoho komisara OON z prav liudyny, 2016, p. 6. 
exigencies of the situation. This raises serious concerns about the proportionality of the derogating measures. There is nothing to prove that the decision to derogate was taken by considering other, less stringent, measures. A notification sent in November outlining the territorial coverage of derogation does not contain justification of derogation use to territories under effective Ukrainian control. 2) The UN Human Rights Committee is a competent body within the UN system that can assess the lawfulness of the derogation. However, this has not yet been done."20

Some of the 29 reports (as of April 30, 2020) of the Office of the United Nations High Commissioner for Human Rights on human rights situation in Ukraine, are based on the work of the United Nations Human Rights Monitoring Mission in Ukraine, set out the shortcomings in the exercise by the State of the right to derogate from certain obligations under the ICCPR, which was reported to the UN Secretary-General. The Office of the UN High Commissioner for Human Rights has indicated the need to proclaim the existence of a public emergency officially (under Article 4 of the ICCPR is a prerequisite for exercising the right of derogation) which threatens the life of the nation, and the proportionality of the measures taken; duration, territorial action (geographical coverage of the derogation must be clearly stated) and the subject of the derogation must be clearly limited by exigencies of the situation; derogation must be consistent with other obligations under international law, in particular with the relevant rules of international humanitarian law. The information provided by the Office of the UN High Commissioner for Human Rights indicates the presence of specific problems in Ukraine with the fulfillment of treaty obligations and the observance of international standards for the protection of human rights, protection of the civilian population, as well as the need to improve and specify them, in taking appropriate measures to ensure and restore the rights of victims of violations (among which are the right to the truth, the right to access to justice, the right to a fair trial, in particular: the right to a public hearing, the right to a impartial tribunal, the right to a trial without undue delay) $(\$ 72,76$, $80-81$, etc. $),{ }^{21}(\$ 59$, etc. $){ }^{22}(\$ 11,56,60,106$, etc. $),{ }^{23}$ compensation for the harm

20 Ibid, p. 4.

21 Report on the human rights situation in Ukraine 16 November 2019 to 15 February 2020. Office of the United Nations High Commissioner for Human Rights, 2020, pp. 15-18. [online]. Available at: <https://www.ohchr.org/Documents/Countries/ UA/29thReportUkraine_EN.pdf $>$ Accessed: 13.03.2020

22 Report on the human rights situation in Ukraine 16 May to 15 August 2019. Office of the United Nations High Commissioner for Human Rights, 2019, p. 15. [online]. Available at: $<$ https://www.ohchr.org/Documents/Countries/UA/ReportUkraine16May-15Aug2019_ EN.pdf> Accessed: 17.03.2020

23 Report on the human rights situation in Ukraine 16 August to 15 November 2019. Office of the United Nations High Commissioner for Human Rights, 2019, pp. 2, 14, 16, 25. [online]. Available at: <https://www.ohchr.org/Documents/Countries/UA/28thReportUkraine EN.pdf> Accessed: 20.03.2020 
caused and the provision of guarantees to prevent repeated violations. In this and related context, international instruments are essential for ensuring accountability and restoring justice concerning the promotion of truth, justice, reparation and guarantees of non-recurrence, ${ }^{24}$ in particular: the UN General Assembly resolution 60/147 on Basic Principles and Guidelines on the Right to a Remedy and Reparation for Victims of Gross Violations of International Human Rights Law and Serious Violations of International Humanitarian Law. ${ }^{25}$

Appropriately noted that all States Parties, having ratified or acceded to the ICCPR, have undertaken to submit to the UN Human Rights Committee as a quasi-judicial authority ${ }^{26}$ exercising supervisory powers with the help of a number of mechanisms aimed at ensuring the proper implementation of the ICCPR, periodic reports on the measures taken and the progress achieved. Ukraine has already submitted seven periodic reports on the implementation of the Covenant's provisions before derogating from some of ICCPR obligations, and the eighth report in July 2018.

It is noteworthy that a somewhat different conceptual vision of the grounds for the lawful derogation of the state from certain obligations in case of emergency is enshrined in Article $27 \$ 1$ "Suspension of Guarantees" of the American Convention on Human Rights (1969) (as of that date, 24 states had ratified), which provides for such possibility "in time of war, public danger, or other emergency that threatens the independence or security of a State Party" 27 rather than "threatens the life of the nation" as defined in Article $4 \$ 1$ of the ICCPR and in Article $15 \$ 1$ of the ECHR. Besides, for comparison, Article $27 \$ 2$ of the American Convention on Human Rights (1969) establishes the most comprehensive list of provisions for which suspension of guarantees is inadmissible, namely: Article 3 (right to juridical personality), Article 4 (right to life), Article 5 (right to humane treatment), Article 6 (freedom from slavery), Article 9 (freedom from "ex post facto" laws), Article 12 (freedom of conscience and religion), Article 17

24 International instruments relating to the promotion of truth, justice, reparation and guarantees of non-recurrence. Office of the United Nations High Commissioner for Human Rights. [online]. Available at: <https://www.ohchr.org/EN/Issues/TruthJusticeReparation/ Pages/InternationalInstruments.aspx $>$ Accessed: 27.02.2020

25 Basic Principles and Guidelines on the Right to a Remedy and Reparation for Victims of Gross Violations of International Human Rights Law and Serious Violations of International Humanitarian Law. Adopted and proclaimed by General Assembly resolution 60/147 (A/Res/60/147) of 16 December 2005. [online]. Available at: <https://www.ohchr. org/EN/ProfessionalInterest/Pages/RemedyAndReparation.aspx > Accessed: 15.03.2020

26 See BURLAK, Oksana. Mizhnarodnyi pakt pro hromadianski i politychni prava 1966. Entsyklopediia mizhnarodnoho prava: U 3 t. Redkol.: Yurii Shemshuchenko, Volodymyr Denysov (spivholovy) ta in.; Instytut derzhavy i prava im. V. M. Koretskoho NAN Ukrainy. T. 3 (M-Ia). Kyiv: Akademperiodyka, 2019, pp. 187, 191.

27 American Convention on Human Rights: "Pact of San José, Costa Rica", 22 November 1969, p. 152. [online]. Available at: <https://treaties.un.org/doc/Publication/UNTS/Volume\%201144/volume-1144-I-17955-English.pdf> Accessed: 11.03.2020 
(rights of the family), Article 18 (right to a name), Article 19 (rights of the child), Article 20 (right to nationality), Article 23 (right to participate in government). ${ }^{28}$

The state must prove: validity of derogation from certain obligations in the field of human rights, expediency and justification, compliance with requirements (compatibility with other international legal obligations, non-discrimination, etc.), existence of legal grounds, conditions and circumstances related to a public emergency. In exceptional cases, the state, in a manner devoid of arbitrariness and not without common sense, has the right to derogate from the fulfillment of certain treaty obligations in the field of human rights in the public emergency due to the threat to the life of the nation, in particular in the case of the armed conflict, mass terrorist act. The derogation notice must be prompt and comprehensive, as required by the international notice regime. The derogation shall be admissible only on official and public notice of the state's derogation from its obligations, on a temporary basis, in limited cases of serious threat, and to the extent required by the exigencies of the situation. According to international standards, the duration, territorial coverage and derogation subject should be clearly limited by the exigencies of the situation, which is a basic requirement for the lawfulness of all derogation measures under the ICCPR. After all, "derogation from certain obligations does not fully exempt the States from fulfilling of those obligations. To be legitimate measures to derogate the obligations must be clearly limited by the exigencies of the situation. Therefore, a State may be found to be in breach of its obligations if the measures taken by it to derogate from these obligations are found to be disproportionate."29 The above indicates that the state has a duty to prove: restrictive measures are reasonably necessary, temporary and legitimate, that is, comply with the treaty legal regime of their application. ${ }^{30}$ Such regime of derogation from international legal obligations in the field of human rights is directly relevant to national law and has implications for enforcement, substantially narrowing the scope of obligations to guarantee human rights in comparison with international standards, as well as the legal guarantees of their observance, national remedies.

In this context, interpretation of the Siracusa Principles on the Limitation and Derogation Provisions in the International Covenant on Civil and Political Rights adopted by the United Nations Economic and Social Council (ECOSOC), which belong to the recommendation acts of particular importance, draws atten-

28 Ibid.

29 Analitychna dovidka pro vidstup Uriadu Ukrainy vid okremykh zobov'iazan zghidno z mizhnarodnymy uhodamy pro prava liudyny, storonoiu yakykh ye Ukraina. 20 travnia 2016 roku. Upravlinnia Verkhovnoho komisara OON z prav liudyny, 2016, p. 4.

30 See HAFNER-BURTON, Emilie, HELFER, Laurence, FARISS, Christopher, Emergency and Escape: Explaining Derogations from Human Rights Treaties. International Organization, 2011, vol. 65(4) 00021, pp. 676-677. [online]. Available at: <https://scholarship. law.duke.edu/cgi/viewcontent.cgi?article=2947\&context=faculty_scholarship > Accessed: 19.02.2020 
tion. It is important that, following the logic of $\$ 42-43$ of the Siracusa Principles, in exercising the right of derogation from the provisions of the mentioned Covenant, a State shall make an official proclamation of the existence of the public emergency threatening the life of the nation in accordance to the advanced prescribed procedures for the proclamation of it. ${ }^{31}$ Separate section E $(\$ 61-70)$, in particular, states that a bona fide proclamation of a public emergency ${ }^{32}$ permits derogation from certain obligations in the field of human rights, but does not authorize a general departure from international obligations, inter alia which apply in a public emergency under the Geneva and International Labor Organization (ILO) Conventions ${ }^{33}$ ( $\$ 66$ ). The 1949 Geneva Conventions for the protection of war victims form the basis which is a kind of code of international humanitarian law, observance to which and ensuring observance under all circumstances retains relevance in the contemporary realities of "hybrid manifestations" of "multimodal actions" to "achieve synergistic effects" conducting of international and non-international armed conflicts. ${ }^{34}$

The possibility for certain derogations in a public emergency is regulated by permissible rules of international law, which are to be interpreted restrictively, and it is supported by international practice, including judicial. Taking into account experience of Albania, Great Britain, Armenia, Georgia, Greece, Ireland, Turkey, France, ${ }^{35}$ availing itself of this right of derogation according to the ECHR and analyzing situations in which they exercised their right to take measures derogating from certain rights and also, by examining the applicable general principles for the introduction and operation of the special legal regime of emergency, it can be concluded that it is the duty of the State concerned to justify itself, first and foremost, based on the bona fide principle, the necessity and

31 The Siracusa Principles on the Limitation and Derogation Provisions in the International Covenant on Civil and Political Rights. U.N. Doc. E/CN.4/1985/4, Annex (1985): United Nations, Economic and Social Council. [online]. Available at: <https://undocs.org/ pdf?symbol=en/E/CN.4/1985/4> Accessed: 11.03.2020

32 See Pro pravovyi rezhym nadzvychainoho stanu: Zakon Ukrainy vid 16 bereznia $2000 \mathrm{r}$. № 1550-III u redaktsii vid 28 hrudnia 2015 r. № 901-VIII. Vidomosti Verkhovnoi Rady Ukrainy, 2000, № 23, St. 176. [online]. Available at: <https://zakon.rada.gov.ua/laws/ show/1550-14> Accessed: 24.02.2020

33 The Siracusa Principles on the Limitation and Derogation Provisions in the International Covenant on Civil and Political Rights. U.N. Doc. E/CN.4/1985/4, Annex (1985): United Nations, Economic and Social Council. [online]. Available at: <https://undocs.org/ pdf?symbol=en/E/CN.4/1985/4> Accessed: 19.02.2020

34 DENYSOV, Volodymyr, FALALIEIEVA, Liudmyla. Vidstup vid mizhnarodno-pravovykh zobov'iazan u sferi prav liudyny $\mathrm{v}$ umovakh zbroinoho konfliktu ta tymchasovoi vtraty kontroliu nad chastynoiu terytorii Ukrainy. Pravovi pytannia deokupatsii ta reintehratsii tymchasovo okupovanykh terytorii Ukrainy. Biuleten monitorynhu zakonodavstva Ukrainy. Naukovo-praktychne vydannia / zah. red. O. L. Kopylenka; Instytut zakonodavstva Verkhovnoi Rady Ukrainy. Vyp. 8. Kyiv: Vyd-vo "Liudmyla", 2020, p. 270.

35 See Derogation in time of emergency. Factsheet prepared by the ECtHR's Press Unit. July 2019, p. 2. [online]. Available at: <https://www.echr.coe.int/Documents/FS_Derogation_ ENG.pdf $>$ Accessed: 18.03.2020 
lawfulness of its derogation from certain human rights obligations to a limited extent and only in the event of an emergency. The Office of the UN High Commissioner for Human Rights states: "Based on the analysis of available information, the legitimacy of the Ukrainian Government's derogation from certain obligations enshrined in the International Covenant on Civil and Political Rights remains in doubt." ${ }^{36}$

Article 15 of the ECHR "Derogation in time of emergency" is a derogation clause. It affords to Contracting States, in exceptional circumstances, the possibility of derogating, in a limited and supervised manner, from their obligations to secure certain rights and freedoms under the Convention (1950). ${ }^{37}$ In view of the provisions under Article 15 of the ECHR and the case law of the ECtHR (judgments in interstate and individual cases, among which: Ireland $v$. the United Kingdom (1978); Bilen v. Turkey (2006); A. and Others v. the United Kingdom (2009); Del Rio Prada v. Spain (2013); Öcalan v. Turkey (2014); Hassan v. the United Kingdom (2014); Sahin Alpay v. Turkey and Mehmet Hasan Altan v. Turkey (2018); Alparslan Altan v. Turkey (2019); Kavala v. Turkey (2019) and others) the right to derogation in the field of human rights is recognized by the States in exceptional circumstances, guaranteed by the ECHR: in a specific territory (territorial principle of the right of derogation), temporary (temporary right of derogation), to a limited extent and with the use of a monitoring mechanism. In Article $15 \$ 1$ of the ECHR defined that "in time of war or other public emergency threatening the life of the nation," ${ }^{\prime 38}$ a state may take measures derogating from its obligations under this international treaty "to the extent strictly required by the exigencies of the situation, provided that such measures are not inconsistent with its other obligations under international law"39 in particular, under those which are applied in emergency situations: the 1949 Geneva Conventions and the Additional Protocols thereto, the 1951 Convention Relating to the Status of Refugees, the 1989 Convention on the Rights of the Child and others.

According to international standards, derogationg measures must be compatible with other international legal obligations of the State concerned, which continue to be applied in an emergency. ${ }^{40}$ Thus, derogation under Article 15 of

36 Analitychna dovidka pro vidstup Uriadu Ukrainy vid okremykh zobov'iazan zghidno z mizhnarodnymy uhodamy pro prava liudyny, storonoiu yakykh ye Ukraina. 20 travnia 2016 roku. Upravlinnia Verkhovnoho komisara OON z prav liudyny, 2016, p. 10.

37 Guide on Article 15 of the European Convention on Human Rights - Derogation in time of emergency. Updated on 31 December 2019. Council of Europe/European Court of Human Rights, 2020, p. 5. [online]. Available at: <https://www.echr.coe.int/Documents/ Guide_Art_15_ENG.pdf $>$ Accessed: 12.03.2020

38 Convention for the Protection of Human Rights and Fundamental Freedoms as amended by Protocols No. 11 and No. 14. Rome, 04.XI.1950. [online]. Available at: <https://rm.coe. int/1680063765> Accessed: 12.03.2020

39 Ibid.

40 See ZAND, Joseph. Article 15 of the European Convention on Human Rights and the Notion of State of Emergency. Journal of the Faculty of Law of Inonu University, 2014, vol. 
the ECHR and Artice 4 of the ICCPR may not be used to justify a breach of other international obligations of the State. Generally speaking, the right of a State to derogate under the ECHR requires the need to comply with the above conditions to prevent the unjustified wide usage of such a right. The importance of such an approach is explained by the fact that the treaty rules do not guarantee but limit human rights, unlike the general focus of international legal instruments in which they are contained. ${ }^{41}$ In this context, it also draws attention to the "the long-established principle that the Convention is intended to guarantee rights that are practical and effective, and not theoretical and illusory" ${ }^{42}(\$ 71)$. At the same time, some rights guaranteed by the ECHR do not allow derogation; it is considered inadmissible, unacceptable under any conditions and circumstances. Thus, Article $15 \$ 2$ of the ECHR prohibits derogation from certain of the rights contained in them: the right to life, except in respect of deaths resulting from lawful acts of war (Article 2); the prohibition of torture and other forms of ill-treatment; (Article 3); the prohibition of slavery or servitude (Article $4 \$ 1$ ); clause of "no punishment without law" (Latin "nulla poena sine lege", Article 7). Similarly, there can be no derogation from the provisions of separate protocols annexed to the ECHR, namely: Article 1 of Protocol No. 6 (abolishing the death penalty in peacetime); Article 1 of Protocol No. 13 (abolishing the death penalty in all circumstances); Article 4 (the right not to be tried or punished twice) of Protocol No. $7 .^{43}$

The condition of procedural requirements compliance is enshrined in Article $15 \$ 3$. Availing itself of the right of derogation, any state shall keep the Secretary General of the Council of Europe fully informed of the measures which it has taken and the reasons therefore. ${ }^{44}$ Furthermore, it shall inform the latter when such measures have ceased to operate and the provisions of the ECHR are again

5, No. 1, pp. 159-224. [online]. Available at: <https://dergipark.org.tr/tr/download/articlefile/208446> Accessed: 24.02.2020

41 See CHEVYCHALOVA, Zhanna. Pravovi pidstavy vidstupu Ukrainy vid okremykh zobov'iazan, vyznachenykh Mizhnarodnym paktom pro hromadianski i politychni prava ta Konventsiieiu pro zakhyst prav liudyny i osnovopolozhnykh svobod. Teoriia i praktyka pravoznavstva, 2017, Vyp. 2 (12), p. 3. [online]. Available at: <file:///D:/Documents\%20 and\%20Settings/Admin/\%D0\%9C\%D0\%BE\%D0\%B8\%20\%D0\%B4\%D0\%BE\%D0\%BA\% D1\%83\%D0\%BC\%D0\%B5\%D0\%BD\%D1\%82\%D1\%8B/Downloads/117278-252472-1PB.PDF> Accessed: 21.02.2020

42 Case of Khlebik v. Ukraine (Application no. 2945/16): Judgment European Court of Human Rights, 25 July 2017. [online]. Available at: <https://hudoc.echr.coe.int/ eng\#\{“itemid”:[“001-175656”]\}> Accessed: 10.03.2020

43 Derogation in time of emergency. Factsheet prepared by the ECtHR's Press Unit. July 2019, p. 1. [online]. Available at: <https://www.echr.coe.int/Documents/FS_Derogation_ENG. pdf> Accessed: 18.03.2020

44 See Guide on Article 15 of the European Convention on Human Rights - Derogation in time of emergency. Updated on 31 December 2019. Council of Europe/European Court of Human Rights, 2020, pp. 11-12. [online]. Available at: <https://www.echr.coe.int/Documents/Guide_Art_15_ENG.pdf $>$ Accessed: 12.03.2020 
being fully observed. On 5 June 2015 Ukraine notified the Secretary General of the Council of Europe by passing a note verbale that the emergency situation - state of the security situation in Donetsk and Luhansk regions - compels the state authorities to apply Article 15 of the ECHR for the purpose to derogate from certain rights enshrined in this international treaty and guaranteed by it. ${ }^{45}$ Subsequent notifications from Ukraine were registered with the General Secretariat of the Council of Europe on 4 November 2015, 30 June 2016, 2 February 2017 and 3 December 2019, demonstrating respect for the State's international legal obligations in the field of human rights.

Herewith monitoring mechanisms and procedures play an important role, appeals to the practice of international jurisdictions, the ECtHR, ${ }^{46}$ and application of international, including European, standards of human rights protection, the importance of which is increased in cases where national legislation is insufficiently defined or where there are other deficiencies and certain lacunas that need to be addressed. In the context of the above Artice 17 "Prohibition of abuse of rights" of the ECHR draw attention, according to which none of the provisions of the latter "may be interpreted as implying for any State... any right to engage in any activity or perform any act aimed at the destruction of any of the rights and freedoms set forth herein or at their limitation to a greater extent than is provided for in the Convention" 47 and Article 18 "Limitation on use of restrictions on rights", according to which "The restrictions permitted under this Convention to the said rights and freedoms shall not be applied for any purpose other than those for which they have been prescribed." ${ }^{48}$ In order to prevent abuse by the state of the right of derogation in the field of human rights obligations, it is appropriate to declare that the derogation must comply with stringent international standards and be subject to strict monitoring mechanisms. ${ }^{49}$ Summarizing Professor Christoph Schreuer states: "1. Foremost and most fundamental is the principle of reasonable accommodation between the necessities of community interests and justified particular individual interests. 2. Derogations must be accompanied by official proclamations and notifications giving all relevant details. 3. Derogations must be subject to effective outside supervision

45 Derogation in time of emergency. Factsheet prepared by the ECtHR's Press Unit. July 2019, p. 2. [online]. Available at: <https://www.echr.coe.int/Documents/FS_Derogation_ENG. pdf $>$ Accessed: 18.03.2020

46 See Guide on Article 15 of the European Convention on Human Rights - Derogation in time of emergency. Updated on 31 December 2019. Council of Europe/European Court of Human Rights, 2020, pp. 5-9. [online]. Available at: https://www.echr.coe.int/Documents/ Guide_Art_15_ENG.pdf> Accessed: 12.03.2020

47 Convention for the Protection of Human Rights and Fundamental Freedoms as amended by Protocols No. 11 and No. 14. Rome, 04.XI.1950. [online]. Available at: <https://rm.coe. int/1680063765> Accessed: 23.02.2020

48 Ibid.

49 SARAH, Joseph, CASTAN, Melissa. The International Covenant on Civil and Political Rights: Cases, Materials, and Commentary. 3rd ed. New York: Oxford University Press, 2013, p. 912. 
in order to prevent abuse. 4. Derogations must be used only in situations of absolute necessity in which other means cannot reasonably be expected to safeguard public order. 5. Derogations must be applied subject to strict proportionality. This means: (a) that the derogation should only apply to those rights which have to be limited to cope with the emergency; and (b) that the limitation should only apply to the extent absolutely required. 6 . Derogations should be withdrawn as soon as circumstances permit." 50

It also actualizes the definition of substantive criteria for assessing of a State's behavior in good faith, observance of bona fide principle in its search for balance, "the difficult compromise between defending national interests and protecting individual rights during public emergencies." ${ }^{51}$ In fact, the bona fide principle is the core of the principle of pacta sunt servanda, which applies not only to treaty but also to international obligations in general, which must be fulfilled in good faith.

\section{Ukraine's international legal position on certain human rights treaty obligations under the armed conflict and temporary loss of control over part of state territory}

Ukraine had decided to use its right to derogate from certain rights obligations under international law in the field of human rights. By Resolution No. 462-VIII of May 21, 2015, the Verkhovna Rada of Ukraine approved its Statement "On the derogation of Ukraine from certain obligations set out in the International Covenant on Civil and Political Rights and the Convention for the Protection of Human Rights and Fundamental Freedoms" 52 (has no retroactive effect), as confirmed by the Law of Ukraine "On Features of State Policy for Ensuring State Sovereignty of Ukraine in Temporarily Occupied Territories in Donetsk and Luhansk Regions" ${ }^{33}$ of January 18, 2018 No. 2268-VIII This is a

50 SCHREUER, Christoph. Derogation of Human Rights in Situations of Public Emergency: The Experience of the European Convention on Human Rights. The Yale Journal of World Public Order, 1982, vol. 9:113, p. 116. [online]. Available at: <https://digitalcommons.law. yale.edu/cgi/viewcontent. cgi? article $=1193 \&$ context=yjil $>$ Accessed: 11.03 .2020

51 MARINIELLO, Triestino. Prolonged emergency and derogation of human rights: Why the European Court should raise its immunity system. German Law Journal, 2019, vol. 20, p. 47. [online]. Available at: <https://www.cambridge.org/core/services/aop-cambridgecore/content/view/B1492F20A3F8C754B93B8DB8545ECBFB/S2071832219000038a.pdf/ prolonged_emergency_and_derogation_of_human_rights_why_the_european_court_ should_raise_its_immunity_system.pdf> Accessed: 26.02.2020

52 Pro Zaiavu Verkhovnoi Rady Ukrainy «Pro vidstup Ukrainy vid okremykh zobov'iazan, vyznachenykh Mizhnarodnym paktom pro hromadianski i politychni prava ta Konventsiieiu pro zakhyst prav liudyny i osnovopolozhnykh svobod»: Postanova Verkhovnoi Rady Ukrainy vid 21 travnia 2015 r. № 462-VIII. Vidomosti Verkhovnoi Rady Ukrainy, 2015, № 29, St. 267. [online]. Available at: <https://zakon.rada.gov.ua/laws/show/462-19> Accessed: 24.03.2020

53 Pro osoblyvosti derzhavnoi polityky iz zabezpechennia derzhavnoho suverenitetu Ukrainy 
derogation from certain obligations set out in Article $2 \$ 3$, Articles 9, 12, 14, 17 of the ICCPR and Articles 5, 6, 8, 13 of the ECHR, until the complete cessation of armed aggression of the Russian Federation, it means until all illegal armed units managed, controlled and funded by the Russian Federation have been withdrawn, Russian occupation troops, their military equipment from the territory of Ukraine, restoration of full control of Ukraine over its state border, restoration of the constitutional order and order in the occupied territory of Ukraine ${ }^{54}$ ( $\$$ 1 of the Resolution). Thus, with respect to the ECHR, Ukraine declared derogation of certain rights, namely: right to liberty and security (Article 5); right to a fair trial (Article 6); right to respect for private and family life (Article 8); right to an effective remedy (Article 13). It is noteworthy that the declared derogation of Ukraine does not concern the rest of the rights, for example, protection of property ensured by Article 1 of the First Protocol to the ECHR. At the same time, due to importance and indisputability of certain fundamental rights, among which are the right to life, the prohibition of torture and inhuman or degrading treatment and punishment, the prohibition of slavery as a "hard core" of human rights, they are guaranteed by international treaties and are nonderogable rights. To such international treaties belong: the 1948 Convention on the Prevention and Punishment of the Crime of Genocide, the 1965 International Convention on the Elimination of All Forms of Racial Discrimination, the 1984 Convention against Torture and Other Cruel, Inhuman or Degrading Treatment or Punishment, the 1987 European Convention for the Prevention of Torture and Inhuman or Degrading Treatment or Punishment and others. For example, States Parties are obliged to provide and protect everyone's right to life guaranteed by Article 2 of the ECHR, even in times of war or other emergency, which threatens the life of the nation, as no derogation from implementation of the obligation under Article $15 \$ 2$ of this international legal act shall be made "except in respect of deaths resulting from lawful acts of war." 55

Ukraine's international legal position is that, due to armed aggression against Ukraine the Russian Federation bears "full responsibility for respecting human rights and implementation of relevant international treaties in the annexed and

na tymchasovo okupovanykh terytoriiakh u Donetskii ta Luhanskii oblastiakh: Zakon Ukrainy vid 18 sichnia 2018 r. № 2268-VIII u redaktsii vid 2 sichnia 2020 r. № 113-IKh. Vidomosti Verkhovnoi Rady Ukrainy, 2018, № 10, St. 54. [online]. Available at: <https:// zakon.rada.gov.ua/laws/show/2268-19> Accessed: 12.03.2020

54 Pro Zaiavu Verkhovnoi Rady Ukrainy «Pro vidstup Ukrainy vid okremykh zobov'iazan, vyznachenykh Mizhnarodnym paktom pro hromadianski i politychni prava ta Konventsiieiu pro zakhyst prav liudyny i osnovopolozhnykh svobod»: Postanova Verkhovnoi Rady Ukrainy vid 21 travnia 2015 r. № 462-VIII. Vidomosti Verkhovnoi Rady Ukrainy, 2015, № 29, St. 267. [online]. Available at: <https://zakon.rada.gov.ua/laws/show/462-19> Accessed: 24.03.2020

55 Convention for the Protection of Human Rights and Fundamental Freedoms as amended by Protocols No. 11 and No. 14. Rome, 04.XI.1950. [online]. Available at: <https://rm.coe. int/1680063765> Accessed: 23.02.2020 
temporarily occupied territory of Ukraine", which is an integral part of it - the Autonomous Republic of Crimea and the City of Sevastopol ${ }^{56}$ ( $\$ 1$ of the Statement), as well as "as a state that actually occupied and control part of the Donetsk and Luhansk regions, is responsible for respecting and protecting human rights in these territories under international humanitarian law and international human rights law" "57 ( $\$ 2$ of the Statement). In fact, the Office of the UN High Commissioner for Human Rights by its Report on the human rights situation in Ukraine that covers the period from 16 November 2019 to 15 February 2020, calls on the Russian Federation in the context of the Autonomous Republic of Crimea and the city of Sevastopol (Ukraine) temporarily occupied by it: a) uphold its obligations as duty bearer under international human rights law in Crimea and respect obligations of an occupying Power pursuant to international humanitarian law; b) ensure proper and unimpeded access of international human rights monitoring missions and human rights non-governmental organisations to Crimea, pursuant to General Assembly resolutions 71/205, 72/190, 73/263, and 74/168; c) end the practice of forcible transfers and deportations of protected persons, including detainees, to areas outside the occupied territory; d) refrain from compelling residents of Crimea to serve in the armed forces of the Russian Federation and end the practice of criminal prosecution for evading military conscription in the annexed by it Crimea ${ }^{58}(\$ 136)$. With respect to Ukraine's derogation from certain obligations under the ICCPR and the ECHR, the derogation concerns the area of the large-scale and long-term counter-terrorist operation since 13 April 2014 and the Joint Forces operation since 30 April 2018. According to the basic principles and rules of international law, Ukraine is the sovereign of these territories and they are an integral part of it. At the same time, it is important that full responsibility for the respect of human rights, the fulfillment of treaty obligations and the compliance with international standards in this area in a temporarily uncontrolled part of the territory of Ukraine rests with the state which exercises effective control over it. "The continuing armed aggression of the Russian Federation against Ukraine, which is accompanied by the commission of war crimes and crimes against humanity, both by the regular Armed Forces of the Russian Federation and by illegal armed formations operated, controlled and financed by the Russian Federation, constitutes a public emergency wich threatens the life of nation" as understood after Article $4 \$ 1$ of the ICCPR and

56 Zaiava Verkhovnoi Rady Ukrainy «Pro vidstup Ukrainy vid okremykh zobov'iazan, vyznachenykh Mizhnarodnym paktom pro hromadianski i politychni prava ta Konventsiieiu pro zakhyst prav liudyny i osnovopolozhnykh svobod». Vidomosti Verkhovnoi Rady Ukrainy, 2015, № 29, St. 267. [online]. Available at: <https://zakon.rada.gov.ua/laws/ show/462-19> Accessed: 24.03.2020

57 Ibid.

58 Report on the human rights situation in Ukraine 16 November 2019 to 15 February 2020. Office of the United Nations High Commissioner for Human Rights, 2020, pp. 32-33. [online]. Available at: <https://www.ohchr.org/Documents/Countries/ UA/29thReportUkraine_EN.pdf> Accessed: 22.03.2020 
Article $15 \$ 1$ of the ECHR ( $\$ 3$ of the Statement). In this context, we would like to note that unlike the derogation provision of the ECHR Article 4 of the ICCPR stipulates that States Parties are entitled to derogate from its provisions only on condition that the state of emergency in a State Party in which the life of a nation is threatened is officially declared. This requirement is essential to the principles of legality and the rule of law, but Ukraine has not officially declared a public of emergency. ${ }^{59}$ To date only Nicaragua (1985), Israel (1991), and Azerbaijan (1993) referred to external aggression for exercising the right to derogate from certain obligations under the ICCPR. ${ }^{60}$ In doing so,all of them officially declared a public of emergency in accordance with the provisions of national law.

The provisions of $\$ 4$ of the Statement also draws attention to: "in order to ensure the vital interests of society and the state in the context of armed aggression of the Russian Federation, the Verkhovna Rada of Ukraine, the Cabinet of Ministers of Ukraine and other state authorities are forced to make decisions that constitute a certain derogation from Ukraine's obligations" under the ICCPR and the ECHR. Taking steps to derogate its obligations, given the freedom of discretion regarding legal responses to prevent a threat to the life of the nation, ${ }^{61}$ Ukraine has amended the existing legislation and adopted a number of legislative acts, including: the Law of Ukraine "On the Administration of Justice and Criminal Proceedings in connection with the Counter-Terrorist Operation"62 of August 12, 2014 No. 1632-VII as of December 15, 2017 No. $2147 \mathrm{a}-$ VIII, aimed at ensuring access to court by changing the territorial jurisdiction of court cases and the consistency of criminal offenses committed in the area of conducting an "counter-terrorist operation"; Law of Ukraine "On Civil-Military Administrations"63 of February 3, 2015 No. 141-VIII as of February 24, 2018 No. 2268-VIII, defining the organization, authority and order of activity of the newly-formed military-civilian administrations as a temporary forced action with elements of a military management organization to ensure

59 Analitychna dovidka pro vidstup Uriadu Ukrainy vid okremykh zobov'iazan zghidno z mizhnarodnymy uhodamy pro prava liudyny, storonoiu yakykh ye Ukraina. 20 travnia 2016 roku. Upravlinnia Verkhovnoho komisara OON z prav liudyny, 2016, p. 5.

60 Ibid.

61 See NUGRAHA, Ignatius, Yordan. Human rights derogation during coup situations. The International Journal of Human Rights, 2018, vol. 22, No. 2, pp. 196-198. [online]. Available at: $<$ https://www.tandfonline.com/doi/pdf/10.1080/13642987.2017.1359551?needAccess= true> Accessed: 25.03.2020

62 Pro zdiisnennia pravosuddia ta kryminalnoho provadzhennia u zv'iazku z provedenniam antyterorystychnoi operatsii: Zakon Ukrainy vid 12 serpnia 2014 № 1632-VII u redaktsii vid 15 hrudnia 2017 r. № 2147a-VIII. Vidomosti Verkhovnoi Rady Ukrainy, 2014, № 39, St. 2009. [online]. Available at: <https://zakon.rada.gov.ua/laws/show/1632-18> Accessed: 29.03.2020

63 Pro viiskovo-tsyvilni administratsii: Zakon Ukrainy vid 3 liutoho 2015 № 141-VIII u redaktsii vid 24 liutoho 2018 r. № 2268-VIII. Vidomosti Verkhovnoi Rady Ukrainy, 2015, № 13, St. 87. [online]. Available at: <https://zakon.rada.gov.ua/laws/show/141-19> Accessed: 27.03.2020 
the safety and normalization of the life of the population in the area of repulsion of armed aggression of the Russian Federation (preamble). According to S.O. Kuznichenko and V. I. Shevchenko, "military-civil administrations... exercise in the respective territory the powers of state administration and local self-government", and use them as "special forms and methods of exercising state power in certain regions of Donetsk and the Luhansk regions, due to the need for timely response to threats of military, political and economic nature". ${ }^{64}$

Among the measures listed in the Statement to derogate in the part of the territory of Ukraine temporarily uncontrolled by the Ukrainian authorities: the maximum duration of preventive detention (remand in custody) of persons suspected of involvement in terrorist activities without a court order has been extended from 72 hours to 30 days. However, this measure "may be considered excessive even in an emergency, as effective judicial review of the lawfulness of detention is one of the essential elements of the right to a fair trial, which must be guaranteed in all circumstances". ${ }^{65}$ In addition, "certain elements of the right to a fair trial are clearly guaranteed by international humanitarian law, and no derogation (such as the presumption of innocence and effective judicial review of the lawfulness of detention) can be justified by any act." ${ }^{\prime 6}$ A special pre-trial investigation regime has been introduced, whereby the powers of investigative judges, in case they are unable to exercise the powers established by the current Criminal Procedure Code of Ukraine, are temporarily transfer to prosecutors who acquire additional procedural rights (concerning the choice of preventive measure, access to documents and property, search, listening to communications, etc.) within the spatial scope of the special pre-trial investigation regime in the face of a threat to the nation's existence. Military-civilian administrations as temporary state bodies in the area of the Donetsk and Luhansk regions have the right to set limitations on presence on the streets and other public places without documents at a certain times of day; temporarily restrict or prohibit the movement of vehicles and pedestrians on the streets, roads and sections of the territory (curfew); to arrange verification of identity documents of individuals, and, if necessary, the inspection of belongings, vehicles, luggage and cargo, offices and housing of citizens and other measures to ensure public safety and order. ${ }^{67}$ Such measures of derogation, while they can be considered as interferences with

64 KUZNICHENKO, Svitlana, SHEVCHENKO, Viktoriia. Viiskovo-tsyvilni administratsii v zoni provedennia Operatsii ob'iednanykh syl: monohrafiia. Odesa, 2019, p. 6.

65 Analitychna dovidka pro vidstup Uriadu Ukrainy vid okremykh zobov'iazan zghidno z mizhnarodnymy uhodamy pro prava liudyny, storonoiu yakykh ye Ukraina. 20 travnia 2016 roku. Upravlinnia Verkhovnoho komisara OON z prav liudyny, 2016, p. 6.

66 Ibid, p. 7.

67 Zaiava Verkhovnoi Rady Ukrainy «Pro vidstup Ukrainy vid okremykh zobov'iazan, vyznachenykh Mizhnarodnym paktom pro hromadianski i politychni prava ta Konventsiieiu pro zakhyst prav liudyny i osnovopolozhnykh svobod». Vidomosti Verkhovnoi Rady Ukrainy, 2015, № 29, St. 267. [online]. Available at: <https://zakon.rada.gov.ua/laws/ show/462-19> Accessed: 24.03.2020 
privacy, are not illegal in substance and content, but their legality depends on the circumstances of each case.

Thus, Ukraine exercises its right to derogate the above obligations in certain areas of Donetsk and Luhansk regions of Ukraine, for the period until the complete termination of the armed aggression of the Russian Federation, restoration of the constitutional order and order in the occupied territory of Ukraine, and notification to the UN Secretary-General, to the Secretary General of the Council of Europe on the continued application of the ICCPR and the $\mathrm{ECHR}^{68}$ ( $\$ 9$ of the Statement). In addition, Ukraine reserves the right to take measures that may be grounds for derogation from treaty obligations under other articles ${ }^{69}$ ( $\$$ 10 of the Statement) of the mentioned international human rights instruments and about which will be notified to the UN Secretary-General and Secretary General of the Council of Europe. The Ministry of Foreign Affairs of Ukraine was instructed to inform the UN Secretary-General and the Secretary General of the Council of Europe about the state of the security situation in Donetsk and Luhansk regions, as well as about the change of territory, which is covered by Ukraine's derogation from its separate obligations under the ICCPR and the $\mathrm{ECHR}^{70}$ ( $\$ 2$ of the Resolution), which provides for the need for appropriate methodological and organizational advisory support.

In accordance with the Regulation approved by the Cabinet of Ministers of Ukraine Resolution No. 281 of April 19, 2017, the Government established an Inter-agency Commission on Ukraine's derogation from obligations under the International Covenant on Civil and Political Rights and the Convention for the Protection of Human Rights and Fundamental Freedoms, ${ }^{71}$ the main tasks of which, in accordance with $₫ 3$ of this Regulation, include consideration of: issues of the scope and territorial application of the derogation provisions of Ukraine from obligations under the latter; up-to-date information on the state of the security situation (escalation/de-escalation of the situation, specifics of the operational-military situation, socio-economic aspects, application of laws and regulations containing provisions derogating from the obligations under the the ICCPR and the ECHR) and human rights situations in the area of armed conflict.

68 Ibid.

69 Ibid.

70 Pro Zaiavu Verkhovnoi Rady Ukrainy "Pro vidstup Ukrainy vid okremykh zobov'iazan, vyznachenykh Mizhnarodnym paktom pro hromadianski i politychni prava ta Konventsiieiu pro zakhyst prav liudyny i osnovopolozhnykh svobod": Postanova Verkhovnoi Rady Ukrainy vid 21 travnia 2015 r. № 462-VIII. Vidomosti Verkhovnoi Rady Ukrainy, 2015, № 29, St. 267. [online]. Available at: <https://zakon.rada.gov.ua/laws/show/462-19> Accessed: 24.03.2020

71 Polozhennia pro Mizhvidomchu komisiiu z pytan vidstupu Ukrainy vid zobov'iazan za Mizhnarodnym paktom pro hromadianski i politychni prava ta Konventsiieiu pro zakhyst prav liudyny i osnovopolozhnykh svobod: Postanova Kabinetu Ministriv Ukrainy vid 19 kvitnia 2017 r. № 281. Uriadovyi kur'ier, 25 kvitnia 2017, № 77. [online]. Available at: <https://zakon.rada.gov.ua/laws/show/281-2017-\%D0\%BF> Accessed: 19.03.2020 
Therefore, the mandate of the Inter-agency Commission includes reviewing the scope and proportionality of the retreat measures, but "the committee meetings and their results are closed to the public".72 Finally, a number of legislative acts and the Verkhovna Rada's Statement of Ukraine's derogation from certain obligations, the Regulations on the formation of the Inter-agency Commission and other normative legal acts require updating, replacing the reference of counterterrorist operation to a reference of the Joint Forces Operation. In this way, they will be in compliance with the Law of Ukraine "On the Features of State Policy for Ensuring State Sovereignty of Ukraine in Temporarily Occupied Territories in Donetsk and Luhansk Regions"73 of January 18, 2018 No. 2268-VIII.

With regard to the applicability of the State's human rights obligations in armed conflict, it should be borne in mind, as Ganna Khrystova noted that "the stricken State maintains a positive human rights commitment to residents of temporarily uncontrolled territories and internally displaced persons," ${ }^{74}$ who, having made a voluntary and conscious choice to reside within internationally recognized national borders, have been forced to leave their homes and have special needs in this regard, the same preserved to people who are forced to reside in a temporarily occupied territory and who are suffering from armed conflict. "Internal displacement continues to be one of the priority directions of the state policy of Ukraine five years after the beginning of the armed aggression of the Russian Federation in Donetsk and Luhansk regions and annexation of the Crimea." ${ }^{\prime 5}$ It is imperative "to facilitate long-term decisions and consistent implementation by the state of its obligations in a situation of internal displacement with the support of international partners,"76 inter alia, using international human rights law instruments. It is important that issues related to internal displacement are for the most part perceived as being within the internal competence of the country concerned and, as a consequence, internally displaced persons remain not protected by any international legal instrument as a legally

72 Report on the human rights situation in Ukraine 16 November 2019 to 15 February 2020. Office of the United Nations High Commissioner for Human Rights, 2020, p. 15. [online]. Available at: <https://www.ohchr.org/Documents/Countries/UA/29thReportUkraine_ EN.pdf> Accessed: 21.03.2020

73 Pro osoblyvosti derzhavnoi polityky iz zabezpechennia derzhavnoho suverenitetu Ukrainy na tymchasovo okupovanykh terytoriiakh u Donetskii ta Luhanskii oblastiakh: Zakon Ukrainy vid 18 sichnia 2018 r. № 2268-VIII u redaktsii vid 2 sichnia 2020 r. № 113-IKh. Vidomosti Verkhovnoi Rady Ukrainy, 2018, № 10, St. 54. [online]. Available at: <https:// zakon.rada.gov.ua/laws/show/2268-19> Accessed: 27.03.2020

74 KHRYSTOVA, Hanna. Pozytyvni zobov'iazannia derzhavy u sferi prav liudyny: suchasni vyklyky: monohrafiia. Kharkiv: Vyd-vo "Pravo", 2018, p. 441.

75 KHRYSTOVA, Hanna, TRALO, Yuliia, BURIAKOVSKA, Kateryna. Natsionalna sudova praktyka z pytan vnutrishnoho peremishchennia: zastosuvannia standartiv Rady Yevropy. Druhe vyd. Kharkiv: Vyd-vo "Pravo", 2019, p. 4.

76 Vdoskonalennia natsionalnoho zakonodavstva Ukrainy stosovno zakhystu prav liudyny vnutrishno peremishchenykh osib. Perehlianutyi bazovyi analiz. Zah. red. Kostiantyn KORKELIIA, Hanna KHRYSTOVA. Kharkiv: Vyd-vo "Pravo", 2019, p. 152. 
binding instrument. It is about thousands of human fates, which actualize particular attention and support measures: ensuring effective national response, further practical implementation of relevant international standards, protection of human rights and the fulfillment of state obligations, while maintaining a culture of responsibility and the rule of law. Thus in twenty-sixth report on the human rights situation in Ukraine that covers period from 16 February to 15 May 2019 and is based on the work of the UN Human Rights Monitoring Mission in Ukraine, taking into account collected information the Office of the UN High Commissioner for Human Rights made recommendations for public authorities to take appropriate response measures. In particular, Parliament of Ukraine: "adopt and harmonize legislation to serve as a base for developing a comprehensive mechanism and administrative procedure for restitution and compensation for property damaged and destroyed during the armed conflict in eastern Ukraine, as well as property, currently in military use" 77 ( $\$ 117 \mathrm{f}$ ) based on an approach of respect for human rights.

Study of ECtHR case law under Article 15 of the ECHR concludes that the international judicial authority pays great attention to the analysis of the basic principles in this field and the available practices of their application, the relevant precedents, as well as to the clarification and development of the norms established by the ECHR, including limited and controlled derogations ${ }^{78}$ given the exclusive nature of this right. The ECtHR will shortly provide an assessment of Ukraine's compliance with the conditions and procedures set out in Article 15 of the ECHR, the necessity and proportionality of taking certain measures in the context of armed conflict and the temporary loss of control over part of the territory of the state. Khlebik v. Ukraine (2017) ECtHR merely stated that "the essential reason why his case had so far not been examined by the appeal court was that his case file was no longer available as a result of the hostilities in the areas the Ukrainian Government did not control"79 $(\$ 70)$ and considered that there had been no violation of the right to fair trial (Article 6 of the ECHR) in the circumstances of the case ${ }^{80}(\$ 81)$. However, the parties did not request the ECtHR to apply Article 15 of the ECHR in the applicant's case, accordingy it noted that "it is not necessary to assess whether the situation complained of was covered

77 Report on the human rights situation in Ukraine 16 February to 15 May 2019. Office of the United Nations High Commissioner for Human Rights, 2019, p. 27. [online]. Available at: $<$ https://www.ohchr.org/Documents/Countries/UA/ReportUkraine16Feb-15May2019_ EN.pdf> Accessed: 22.03.2020

78 See: Guide on Article 15 of the European Convention on Human Rights - Derogation in time of emergency. Updated on 31 December 2019. Council of Europe/European Court of Human Rights, 2020. 14 p. URL: <https://www.echr.coe.int/Documents/Guide_Art_15_ ENG.pdf> Accessed: 17.03.2020

79 Case of Khlebik v. Ukraine (Application no. 2945/16): Judgment European Court of Human Rights, 25 July 2017. [online]. Available at: <https://hudoc.echr.coe.int/ eng\#\{“itemid”:[“001-175656”]\}> Accessed: 29.03.2020

80 Ibid. 
by a valid derogation made by Ukraine under Article 15 of the Convention"81 ( $\$ 82)$. According to the ECtHR's legal positions, in particular in Brannigan and McBride v. the United Kingdom (1993), on the circumstances and requirements of applying the derogation under the ECHR, in accordance with the principle of subsidiarity, it is for the particular State to determine which measures are most appropriate, acceptable and efficient in the context of a public emergency, since it has a direct obligation to strike a balance between taking effective measures to combat terrorism on the one hand and respect for human rights on the other. ${ }^{82}$

It is appropriate to note that on October 20,2015, Ukraine informed the UN Secretary-General of the peculiarities of territorial application and fulfillment of its obligations under 16 international treaties made within or under the auspices of the United Nations, which are restricted and not guaranteed in respect of part of the territory of Ukraine temporarily occupied or not under the control of the Ukrainian authorities. Among the following international treaties are: the 1973 Convention on the Prevention and Punishment of Crimes against Persons Enjoying International Protection, including Diplomatic Agents; the 1984 Convention against Torture and Other Cruel, Inhuman or Degrading Treatment or Punishment; the 1997 International Convention for the Suppression of Bomb against Terrorism; the 1999 International Convention for the Suppression of the Financing of Terrorism; the 2000 United Nations Convention against Transnational Organized Crime; the 2003 United Nations Convention against Corruption; the 2005 International Convention for the Suppression of Acts of Nuclear Terrorism..$^{83}$ Ukraine continues this practice, thus, on March 30, 2016, it declared the features of territorial application and fulfillment of its obligations under the Convention on the Prohibition of the Use, Stockpiling, Production and Transfer of Anti-personnel Mines and on their Destruction in 1997. The reports say that temporally this will continue until the sovereignty is fully restored by Ukraine over its entire territory. It is noteworthy that in such cases it is not a matter of derogating from the certain human rights guaranteed by these international treaties. Moreover, the derogation of the 1984 Convention against Torture and Other Cruel, Inhuman or Degrading Treatment or Punishment, as noted earlier, is not permitted. Despite the fact that the Ukrainian authorities are deprived of the opportunity to perform their functions in certain parts of the state territory that are temporarily not under the control of Ukraine, it still has a positive obligation to take all appropriate and accessible legal, diplomatic and other measures for the protection of human rights. "The extent of such obligations depends on the particu-

81 Ibid.

82 Case of Brannigan and McBride v. the United Kingdom (Application no. 14553/89; 14554/89): Judgment European Court of Human Rights, 25 May 1993. [online]. Available at: <https://hudoc.echr.coe.int/fre\#\{“itemid”:[“001-57819”]\}> Accessed: 24.03.2020

83 See Status of Treaties. [online]. Available at: <https://treaties.un.org/Pages/Treaties. aspx?id=4\&subid=A\&lang=en $>$ Accessed: 11.04 .2020 
lar circumstances and rights involved." ${ }^{4}$ The legal implications of the foregoing were of concern of the Office of the UN High Commissioner for Human Rights, which indicates that this creates legal uncertainty and, depending on its interpretation, the possibility to weaken human rights protection. ${ }^{85}$ In addition, on October 16, 2015, Ukraine informed the Secretary General of the Council of Europe of the peculiarities of territorial application and fulfillment of its obligations under the 19 international treaties on human rights concluded within the Council of Europe, that is also not a derogation from certain human rights guaranteed by these international treaties.

Eventually, On 26 November 2019, Ukraibe issued a notification to the UN Secretary-General, which is acting as depositary of all the other States Parties, ${ }^{86}$ notifying him of changes in the material and territorial scope of its derogation from the ICCPR (Article 4) and the ECHR (Article 15). The changes are connected to the enactment of Law of Ukraine "On particular aspects of public policy aimed at safeguarding the sovereignty of Ukraine over the temporarily occupied territory of the Donetsk and Luhansk regions of Ukraine" No. 2268VIII of 18 January $2018^{87}$ and launching from April 2018 Joint Forces Operation. Ukraine suspended derogation under Article 14 of the ICCPR and Article 6 of the ECHR, which guarantees the right to a fair trial, on the transfer of the territorial jurisdiction of court cases from courts located in a non-Ukrainian controlled part of the territory of Ukraine to courts located in the rest of the government-controlled state territory. According to Article 1 of the Law of Ukraine "On the Administration of Justice and Criminal Proceedings in connection with the Counter-Terrorist Operation" of 12 August 2014 No. 1632-VII as amended on December 15, 2017 No. 2147a-VIII, ${ }^{88}$ taking into account the impossibility of sending justice to the courts in the area of the Joint Forces Operation, the consideration of civil, administrative, economic and criminal cases is attributed to the

84 Analitychna dovidka pro vidstup Uriadu Ukrainy vid okremykh zobov'iazan zghidno z mizhnarodnymy uhodamy pro prava liudyny, storonoiu yakykh ye Ukraina. 20 travnia 2016 roku. Upravlinnia Verkhovnoho komisara OON z prav liudyny, 2016, p. 12.

85 Ibid.

86 Notification in accordance with the obligations of the Government of Ukraine under Article 4, para. 3, of the International Covenant on Civil and Political Rights. 26 November 2019. [online]. Available at: <https://treaties.un.org/doc/Publication/CN/2019/ CN.618.2019-Eng.pdf> Accessed: 13.04.2020

87 Pro osoblyvosti derzhavnoi polityky iz zabezpechennia derzhavnoho suverenitetu Ukrainy na tymchasovo okupovanykh terytoriiakh u Donetskii ta Luhanskii oblastiakh: Zakon Ukrainy vid 18 sichnia 2018 r. № 2268-VIII u redaktsii vid 2 sichnia 2020 r. № 113-IKh. Vidomosti Verkhovnoi Rady Ukrainy, 2018, № 10, St. 54. [online]. Available at: <https:// zakon.rada.gov.ua/laws/show/2268-19> Accessed: 10.04.2020

88 Pro zdiisnennia pravosuddia ta kryminalnoho provadzhennia u zv'iazku z provedenniam antyterorystychnoi operatsii: Zakon Ukrainy vid 12 serpnia 2014 № 1632-VII u redaktsii vid 15 hrudnia 2017 r. № 2147a-VIII. Vidomosti Verkhovnoi Rady Ukrainy, 2014, № 39, St. 2009. [online]. Available at: <https://zakon.rada.gov.ua/laws/show/1632-18> Accessed: 24.03.2020 
jurisdiction of courts located in the Government-controlled territory of Ukraine. This changed the rules on the territorial jurisdiction of court cases. Obviously, the Government ceased derogation from Article 14 of the ICCPR and Article 6 of the ECHR, based on ECtHR's decisions that recognized the measure did not violate the right to a fair trial (Khlebik v. Ukraine (2017);99 Tsezar and Others v. Ukraine $\left.(2018)^{90}\right)$.

The Government of Ukraine also notified the UN Secretary-General stating that measures invoked in the area of the counter-terrorism operation (started April 13, 2014), namely the extension of the maximum period of preventive detention of suspects in terrorism-related cases without a court review from 72 hours to 30 days and the transfer of certain powers held by investigative judges to prosecutors - are not applicable to the Joint Forces Operation ${ }^{91}$ which was enacted on 30 April 2018. Implementation of these measures may imply a derogation from Ukraine's obligations under Articles 9, 12, 17 of the ICCPR, Articles 5, 8 of the ECHR, and Article 2 of the Protocol No. 4 thereto and necessitates the continuation of such a derogation ${ }^{92}(\$ 2)$. Although formally these measures remain in force in Ukrainian legislation. It is noteworthy that at the end of 2019 for the first time Ukraine has altered the material scope of its derogation. Welcoming the outlined positive development, the Office of the UN High Commissioner for Human Rights encouraged the Government of Ukraine to conduct regular and transparent reviews of the necessity and proportionality of its derogation and to lift it as soon as possible ${ }^{93}$ ( $\$ 71$ ). To the Inter-agency commission on the derogation of the Government of Ukraine from the International Covenant on Civil and Political Rights and the Convention for the Protection of Human Rights and Fundamental Freedoms is recommended to: "carry out regular periodic reviews of the necessity and proportionality of the Government's derogation measures, publish the results of such reviews, and lift the derogation as soon as possible"94 ( $\$ 133 \mathrm{~h}$ ). Besides the Office of the United Nations High Com-

89 Case of Khlebik v. Ukraine (Application no. 2945/16): Judgment European Court of Human Rights, 25 July 2017. [online]. Available at: <https://hudoc.echr.coe.int/ eng\#\{“itemid”:[“001-175656”]\}> Accessed: 11.04.2020

90 Case of Tsezar and Others v. Ukraine (Applications nos. 73590/14, 73593/14, 73820/14, 4635/15, 5200/15, 5206/15 and 7289/15): Judgment European Court of Human Rights, 13 February 2018. [online]. Available at: <https://hudoc.echr.coe.int/ eng\#\{“itemid":[“001-180845”]\}> Accessed: 24.03.2020

91 Notification in accordance with the obligations of the Government of Ukraine under Article 4, para. 3, of the International Covenant on Civil and Political Rights. 26 November 2019. [online]. Available at: <https://treaties.un.org/doc/Publication/CN/2019/ CN.618.2019-Eng.pdf > Accessed: 24.03.2020

92 Ibid.

93 Report on the human rights situation in Ukraine 16 November 2019 to 15 February 2020. Office of the United Nations High Commissioner for Human Rights, 2020, p. 15. [online]. Available at: <https://www.ohchr.org/Documents/Countries/UA/29thReportUkraine_ EN.pdf> Accessed: 28.03.2020

94 Ibid, p. 31. 
missioner for Human Rights recalls that "all parties to the conflict have obligations under international human rights and humanitarian law. Individuals may be held criminally responsible, not only domestically, but internationally, when war crimes are committed"95 ( $\$ 130)$. In the light of the above, the Office of the UN High Commissioner for Human Rights recommends that the international community, inter alia, "continue using all diplomatic means to press all parties to immediately end hostilities, emphasising how the active armed conflict causes suffering of civilians and hampers prospects for stability, peace..."96 (\$137 a). In the face of prolonged armed conflict and the temporary loss of control of part of the territory of Ukraine by the Ukrainian authorities, in order to ensure the optimal use of any means of protection, the state must first and foremost exercise legal capacity, ensuring that the Russian Federation exercises overall control over the relevant part territories of Ukraine, which violations of international law have been committed by it, and what legal instruments of protection can be applied in accessible international human rights protection mechanisms.

\section{Conclusion}

Summarizing the above, in Ukraine, therefore, in Europe, there is a prolonged armed conflict, which grossly and systematically violates human rights, which actualises the need to expand the ability to comply with international standards and to build the capacity to fulfill international treaty obligations in the field of protection of human rights, protection of the civilian population. The derogation measures, inter alia, aim to deprive the subjects of law of effectively challenge in court the decisions and/or actions of the State, based on special legislation. In Ukraine, it was adopted in connection with the armed conflict and the temporary occupation of part of the state territory. However, the large-scale and long-lasting counter-terrorism operation has not been replaced by the Joint Forces Operation at the legislative level, which began in April 2018. The above emphasizes the importance of timely legislative changes, ensuring the legislative dynamics, as the current legal framework requires updating and improvement, alignment with practice. The necessity for periodic review of the need to maintain measures related to the derogation for the restriction of material scope of application and territorial coverage is relevant and will remain relevant until the full restoration of the constitutional order and control over the relevant part of the territory of Ukraine.

In exercising its right to derogation of human rights, Ukraine has not fully followed the rules of international law, notably on the official declaration of a state of emergency as a requirement under the ICCPR, the promptness and completeness of the notice of derogation as required international message mode. In all circumstances, the assessment of the legality of Ukraine's derogation under

95 Ibid, p. 30.

96 Ibid, p. 33.

Published by Palacký University Olomouc, Czech Republic, 2020.

ISSN (print): 1213-8770; ISSN (online): 2464-6601 
the ICCPR can be provided by the UN Human Rights Committee as a competent body within the UN system, and under the ECHR - by the ECtHR as a convention control mechanism. At the same time, it should be borne in mind that, without resorting to derogations during armed conflict and the temporary loss of control of part of the territory of Ukraine, the state would be responsible for breach of treaty obligations, in particular under the ECHR, and its provisions would be interpreted taking into account the principles and norms of international humanitarian law as relevant factors for the protection of human rights, protection of the civilian population in the face of the humanitarian challenges of today.

\section{List of references}

ABDELGAWAD, Elisabeth, Lambert. European Court of Human Rights. The Council of Europe: Its Law and Policies. Ed. by Stefanie Schmahl, Marten Breuer. Oxford: Oxford University Press, 2017, pp. 228-268.

Analitychna dovidka pro vidstup Uriadu Ukrainy vid okremykh zobov'iazan zghidno z mizhnarodnymy uhodamy pro prava liudyny, storonoiu yakykh ye Ukraina. 20 travnia 2016 roku. Upravlinnia Verkhovnoho komisara OON z prav liudyny, 2016, 12 p. (in Ukrainian).

BURLAK, Oksana. Mizhnarodnyi pakt pro hromadianski i politychni prava 1966. Entsyklopediia mizhnarodnoho prava: U 3 t. Redkol.: Yurii Shemshuchenko, Volodymyr Denysov (spivholovy) ta in.; Instytut derzhavy i prava im. V. M. Koretskoho NAN Ukrainy. T. 3 (M-Ia). Kyiv: Akademperiodyka, 2019, pp. 187-191. (in Ukrainian).

BUROMENSKYI, Mykhailo. Yevropeiskyi kodeks svobody ta demokratii. Pravo Ukrainy, 2010, № 10, pp. 89-97. (in Ukrainian).

CHEVYCHALOVA, Zhanna. Pravovi pidstavy vidstupu Ukrainy vid okremykh zobov'iazan, vyznachenykh Mizhnarodnym paktom pro hromadianski i politychni prava ta Konventsiieiu pro zakhyst prav liudyny i osnovopolozhnykh svobod. Teoriia $i$ praktyka pravoznavstva, 2017, Vyp. 2 (12), pp. 1-24. [online]. Available at: <file:///D:/ Documents\%20and\%20Settings/Admin/\%D0\%9C\%D0\%BE\%D0\%B8\%20\%D0\% B4\%D0\%BE\%D0\%BA\%D1\%83\%D0\%BC\%D0\%B5\%D0\%BD\%D1\%82\%D1\%8B/ Downloads/117278-252472-1-PB.PDF> (in Ukrainian).

DENYSOV, Volodymyr. Pryntsypy mizhnarodnoho prava. Entsyklopediia mizhnarodnoho prava: U 3 t. Redkol.: Yurii Shemshuchenko, Volodymyr Denysov (spivholovy) ta in.; Instytut derzhavy i prava im. V. M. Koretskoho NAN Ukrainy. T. 3 (M-Ia). Kyiv: Akademperiodyka, 2019, pp. 622-624. (in Ukrainian).

DENYSOV, Volodymyr, FALALIEIEVA, Liudmyla. Vidstup vid mizhnarodno-pravovykh zobov'iazan u sferi prav liudyny $\mathrm{v}$ umovakh zbroinoho konfliktu ta tymchasovoi vtraty kontroliu nad chastynoiu terytorii Ukrainy. Pravovi pytannia deokupatsii ta reintehratsii tymchasovo okupovanykh terytorii Ukrainy. Biuleten monitorynhu zakonodavstva Ukrainy. Naukovo-praktychne vydannia / zah. red. O. L. Kopylenka; Instytut zakonodavstva Verkhovnoi Rady Ukrainy. Vyp. 8. Kyiv: Vyd-vo "Liudmyla", 2020, pp. 260-285. (in Ukrainian).

DENYSOV, Volodymyr, FALALIEIEVA, Liudmyla. Nadnatsionalnist yak pravova realnist mizhnarodnoi intehratsii. Pravo Ukrainy, 2018, № 1, pp. 214-231. (in Ukrainian). 
DÖRR, Oliver. European Convention on Human Rights. The Council of Europe: Its Law and Policies. Ed. by Stefanie Schmahl, Marten Breuer. Oxford: Oxford University Press, 2017, pp. 465-506.

FALALIEIEVA, Liudmyla. Rada Yevropy ta Yevropeiskyi Soiuz: osoblyvosti pravovoho statusu, uzghodzhennia standartiv pravozakhystu. Visnyk Kyivskoho natsionalnoho universytetu imeni Tarasa Shevchenka. Mizhnarodni vidnosyny, 2018, vypusk 1/2 (47/48), pp. 55-65. (in Ukrainian).

FALALIEIEVA, Liudmyla. Rada Yevropy. Entsyklopediia mizhnarodnoho prava: U 3 t. Redkol.: Yurii Shemshuchenko, Volodymyr Denysov (spivholovy) ta in.; Instytut derzhavy i prava im. V. M. Koretskoho NAN Ukrainy. T. 3 (M-Ia). Kyiv: Akademperiodyka, 2019, pp. 661-666. (in Ukrainian).

HAFNER-BURTON, Emilie, HELFER, Laurence, FARISS, Christopher. Emergency and Escape: Explaining Derogations from Human Rights Treaties. International Organization, 2011, vol. 65(4) 00021, pp. 673-707. [online]. Available at: <https://scholarship.law.duke.edu/cgi/viewcontent.cgi?article=2947\&context=faculty_scholarship $>$

KHRYSTOVA, Hanna. Pozytyvni zobov'iazannia derzhavy u sferi prav liudyny: suchasni vyklyky: monohrafiia. Kharkiv: Vyd-vo "Pravo", 2018, 680 p. (in Ukrainian).

KHRYSTOVA, Hanna, TRALO, Yuliia, BURIAKOVSKA, Kateryna. Natsionalna sudova praktyka $z$ pytan vnutrishnoho peremishchennia: zastosuvannia standartiv Rady Yevropy. Druhe vyd. Kharkiv: Vyd-vo "Pravo", 2019, 265 p. (in Ukrainian).

KUZNICHENKO, Svitlana, SHEVCHENKO, Viktoriia. Viiskovo-tsyvilni administratsii $v$ zoni provedennia Operatsii ob'iednanykh syl: monohrafiia. Odesa, 2019, 170 p. (in Ukrainian).

MARINIELLO, Triestino. Prolonged emergency and derogation of human rights: Why the European Court should raise its immunity system. German Law Journal, 2019, vol. 20, pp. 46-71. [online]. Available at: <https://www.cambridge.org/core/services/aop-cambridge-core/content/view/B1492F20A3F8C754B93B8DB8545ECBFB/ S2071832219000038a.pdf/prolonged_emergency_and_derogation_of_human_ rights_why_the_european_court_should_raise_its_immunity_system.pdf > .

MYTSYK, Vsevolod. Yevropeiska konventsiia pro zakhyst prav liudyny i osnovopolozhnykh svobod 1950. Entsyklopediia mizhnarodnoho prava: U 3 t. Redkol.: Yurii Shemshuchenko, Volodymyr Denysov (spivholovy) ta in.; Instytut derzhavy i prava im. V. M. Koretskoho NAN Ukrainy. T. 2 (E-L). Kyiv: Akademperiodyka, 2017, pp. 127131. (in Ukrainian).

NUGRAHA, Ignatius, Yordan. Human rights derogation during coup situations. The International Journal of Human Rights, 2018, vol. 22, No. 2, pp. 194-206. [online]. Available at: <https://www.tandfonline.com/doi/pdf/10.1080/13642987.2017.135955 1 ? needAccess $=$ true $>$.

SARAH, Joseph, CASTAN, Melissa. The International Covenant on Civil and Political Rights: Cases, Materials, and Commentary. 3rd ed. New York: Oxford University Press, 2013, 989 p.

SCHREUER, Christoph. Derogation of Human Rights in Situations of Public Emergency: The Experience of the European Convention on Human Rights. The Yale Journal of World Public Order, 1982, vol. 9:113, pp. 113-132. [online]. Available at: <https:// digitalcommons.law.yale.edu/cgi/viewcontent.cgi? article $=1193 \&$ context=yjil $>$. 
Vdoskonalennia natsionalnoho zakonodavstva Ukrainy stosovno zakhystu prav liudyny vnutrishno peremishchenykh osib. Perehlianutyi bazovyi analiz. Zah. red. Kostiantyn KORKELIIA, Hanna KHRYSTOVA. Kharkiv: Vyd-vo "Pravo", 2019, 204 p. (in Ukrainian).

ZADOROZHNII, Oleksandr. Aneksiia Krymu - mizhnarodnyi zlochyn: monohrafiia. Kyiv: K.I.S., 2015, 576 p. (in Ukrainian).

ZADOROZHNII, Oleksandr. Mizhnarodne pravo $v$ mizhderzhavnykh vidnosynakh Ukrainy i Rosiiskoi Federatsii 1991-2014: monohrafiia. Kyiv: K.I.S., 2014, 960 p. (in Ukrainian).

ZAND, Joseph. Article 15 of the European Convention on Human Rights and the Notion of State of Emergency. Journal of the Faculty of Law of Inonu University, 2014, vol. 5, No. 1, pp. 159-224. [online]. Available at: <https://dergipark.org.tr/tr/download/ article-file/208446>.

\section{International documents}

American Convention on Human Rights: “Pact of San José, Costa Rica”. 22 November 1969. [online]. Available at: <https://treaties.un.org/doc/Publication/UNTS/Volume\%20 1144/volume-1144-I-17955-English.pdf $>$.

Basic Principles and Guidelines on the Right to a Remedy and Reparation for Victims of Gross Violations of International Human Rights Law and Serious Violations of International Humanitarian Law. Adopted and proclaimed by General Assembly resolution 60/147 (A/Res/60/147) of 16 December 2005. [online]. Available at: <https://www. ohchr.org/EN/ProfessionalInterest/Pages/RemedyAndReparation.aspx $>$.

Convention for the Protection of Human Rights and Fundamental Freedoms as amended by Protocols No. 11 and No. 14. Rome, 04.XI.1950. [online]. Available at: <https:// rm.coe.int/1680063765>.

Council of Europe Action Plan for Ukraine 2018-2021. GR-DEM(2017)18. 21 February 2018. Document prepared by the Office of the Directorate General of Programmes. Document approved by the Committee of Ministers of the Council of Europe on 21 February 2018 (CM/Del/Dec(2018)1308/2.1bisc), 43 p.

Derogation in time of emergency. Factsheet prepared by the ECtHR's Press Unit. July 2019, 16 p. [online]. Available at: <https://www.echr.coe.int/Documents/FS_Derogation_ ENG.pdf $>$.

Guide on Article 15 of the European Convention on Human Rights - Derogation in time of emergency. Updated on 31 December 2019. Council of Europe/European Court of Human Rights, 2020, 14 p. [online]. Available at: <https://www.echr.coe.int/Documents/Guide_Art_15_ENG.pdf >.

International Covenant on Civil and Political Rights. New York, 19 December 1966. [online]. Available at:<http://www.un.org.ua/images/International_Covenant_on_ Civil_and_Political_Rights_CCPR_eng1.pdf $>$.

International instruments relating to the promotion of truth, justice, reparation and guarantees of non-recurrence. Office of the United Nations High Commissioner for Human Rights. [online]. Available at: <https://www.ohchr.org/EN/Issues/TruthJusticeReparation/Pages/InternationalInstruments.aspx $>$.

Notification in accordance with the obligations of the Government of Ukraine under Article 4, para. 3, of the International Covenant on Civil and Political Rights. 26 November 2019. [online]. Available at: <https://treaties.un.org/doc/Publication/CN/2019/ CN.618.2019-Eng.pdf $>$. 
Report on the human rights situation in Ukraine 16 August to 15 November 2019. Office of the United Nations High Commissioner for Human Rights, 2019, 29 p. [online]. Available at: <https://www.ohchr.org/Documents/Countries/UA/28thReportUkraine_ EN.pdf $>$.

Report on the human rights situation in Ukraine 16 February to 15 May 2019. Office of the United Nations High Commissioner for Human Rights, 2019, 30 p. [online]. Available at: <https://www.ohchr.org/Documents/Countries/UA/ReportUkraine16Feb15May2019_EN.pdf>.

Report on the human rights situation in Ukraine 16 May to 15 August 2019. Office of the United Nations High Commissioner for Human Rights, 2019, 30 p. [online]. Available at: <https://www.ohchr.org/Documents/Countries/UA/ReportUkraine16May15Aug2019_EN.pdf>.

Report on the human rights situation in Ukraine 16 November 2019 to 15 February 2020. Office of the United Nations High Commissioner for Human Rights, 2020, 46 p. [online]. Available at: <https://www.ohchr.org/Documents/Countries/ UA/29thReportUkraine_EN.pdf>.

Status of International Covenant on Civil and Political Rights. New York, 19 December 1966. [online]. Available at: <https://treaties.un.org/Pages/ViewDetails. aspx?src=TREATY\&mtdsg_no=IV-4\&chapter=4\&clang=_en $>$.

Statute of the Council of Europe and texts of statutory character. London, 5.V.1949. [online]. Available at:<https://rm.coe.int/CoERMPublicCommonSearchServices/ DisplayDCTMContent?document Id=0900001680935bd5>.

The Siracusa Principles on the Limitation and Derogation Provisions in the International Covenant on Civil and Political Rights. U.N. Doc. E/CN.4/1985/4, Annex (1985): United Nations, Economic and Social Council, 12 p. [online]. Available at: <https:// undocs.org/pdf?symbol=en/E/CN.4/1985/4>.

\section{Domestic law}

Polozhennia pro Mizhvidomchu komisiiu z pytan vidstupu Ukrainy vid zobov'iazan za Mizhnarodnym paktom pro hromadianski i politychni prava ta Konventsiieiu pro zakhyst prav liudyny i osnovopolozhnykh svobod: Postanova Kabinetu Ministriv Ukrainy vid 19 kvitnia 2017 r. № 281. Uriadovyi kur'ier, 25 kvitnia 2017, № 77. [online]. Available at: <https://zakon.rada.gov.ua/laws/show/281-2017-\%D0\%BF> (in Ukrainian).

Pro osoblyvosti derzhavnoi polityky iz zabezpechennia derzhavnoho suverenitetu Ukrainy na tymchasovo okupovanykh terytoriiakh u Donetskii ta Luhanskii oblastiakh: Zakon Ukrainy vid 18 sichnia 2018 r. № 2268-VIII u redaktsii vid 2 sichnia 2020 r. № 113-IKh. Vidomosti Verkhovnoi Rady Ukrainy, 2018, № 10, St. 54. [online]. Available at: $<$ https://zakon.rada.gov.ua/laws/show/2268-19> (in Ukrainian).

Pro pravovyi rezhym nadzvychainoho stanu: Zakon Ukrainy vid 16 bereznia 2000 r. № 1550-III u redaktsii vid 28 hrudnia 2015 r. № 901-VIII. Vidomosti Verkhovnoi Rady Ukrainy, 2000, № 23, St. 176. [online]. Available at: <https://zakon.rada.gov.ua/laws/ show/1550-14> (in Ukrainian).

Pro viiskovo-tsyvilni administratsii: Zakon Ukrainy vid 3 liutoho 2015 № 141-VIII u redaktsii vid 24 liutoho 2018 r. № 2268-VIII. Vidomosti Verkhovnoi Rady Ukrainy, 2015, № 13, St. 87. [online]. Available at: <https://zakon.rada.gov.ua/laws/show/14119> (in Ukrainian). 
Pro vykonannia rishen ta zastosuvannia praktyky Yevropeiskoho sudu z prav liudyny: Zakon Ukrainy vid 23 liutoho 2006 r. № 3477-IV u redaktsii vid 2 hrudnia 2012 r. № 5463-VI. Vidomosti Verkhovnoi Rady Ukrainy, 2006, № 30, St. 260. [online]. Available at: <https://zakon.rada.gov.ua/laws/show/3477-15> (in Ukrainian).

Pro Zaiavu Verkhovnoi Rady Ukrainy “Pro vidstup Ukrainy vid okremykh zobov’iazan, vyznachenykh Mizhnarodnym paktom pro hromadianski i politychni prava ta Konventsiieiu pro zakhyst prav liudyny i osnovopolozhnykh svobod": Postanova Verkhovnoi Rady Ukrainy vid 21 travnia 2015 r. № 462-VIII. Vidomosti Verkhovnoi Rady Ukrainy, 2015, № 29, St. 267. [online]. Available at: <https://zakon.rada.gov.ua/laws/ show/462-19> (in Ukrainian).

Pro zdiisnennia pravosuddia ta kryminalnoho provadzhennia u zv'iazku z provedenniam antyterorystychnoi operatsii: Zakon Ukrainy vid 12 serpnia 2014 № 1632VII u redaktsii vid 15 hrudnia 2017 r. № 2147a-VIII. Vidomosti Verkhovnoi Rady Ukrainy, 2014, № 39, St. 2009. [online]. Available at: <https://zakon.rada.gov.ua/laws/ show/1632-18> (in Ukrainian).

Zaiava Verkhovnoi Rady Ukrainy "Pro vidstup Ukrainy vid okremykh zobov'iazan, vyznachenykh Mizhnarodnym paktom pro hromadianski i politychni prava ta Konventsiieiu pro zakhyst prav liudyny i osnovopolozhnykh svobod". Vidomosti Verkhovnoi Rady Ukrainy, 2015, № 29, St. 267. [online]. Available at: <https://zakon.rada.gov. ua/laws/show/462-19> (in Ukrainian).

Case law

Case of A. and Others $v$. the United Kingdom (Application no. 3455/05): Judgment European Court of Human Rights, 19 February 2009. [online]. Available at: <https:// hudoc.echr.coe.int/eng\#\{“itemid”:[“001-91403”]\}>.

Case of Bosphorus Hava Yollari Turizm ve Ticaret Anonim Şirketi v. Ireland (Application no. 45036/98, p. 156): Judgment European Court of Human Rights, 30 June 2005. [online]. Available at: <https://hudoc.echr.coe.int/eng\#\{“itemid”:[“001-69564”]\}>.

Case of Brannigan and McBride v. the United Kingdom (Application no. 14553/89; 14554/89): Judgment European Court of Human Rights, 25 May 1993. [online]. Available at: <https://hudoc.echr.coe.int/fre\#\{“itemid”:[“001-57819”]\}>.

Case of Khlebik v. Ukraine (Application no. 2945/16): Judgment European Court of Human Rights, 25 July 2017. [online]. Available at: <https://hudoc.echr.coe.int/ eng\#\{“itemid":[“001-175656”]\}>.

Case of Kjeldsen, Busk Madsen and Pedersen v. Denmark (Application no. 5095/71; 5920/72; 5926/72): Judgment European Court of Human Rights, 7 December 1976. [online]. Available at: <https://www.globalhealthrights.org/wp-content/uploads/2013/10/ Kjeldsen-Denmark-1976.pdf>.

Case of Lawless v. Ireland (No. 3) (Application no. 332/57): Judgment European Court of Human Rights, 1 July 1961. [online]. Available at: <https://hudoc.echr.coe.int/ eng\#\{“itemid”: [“001-57518”]\}>.

Case of Tsezar and Others v. Ukraine (Applications nos. 73590/14, 73593/14, 73820/14, 4635/15, 5200/15, 5206/15 and 7289/15): Judgment European Court of Human Rights, 13 February 2018. [online]. Available at: <https://hudoc.echr.coe.int/ eng\#\{“itemid":[“001-180845”]\}>. 